\title{
Empire and enterprise
}

Money, power and the Adventurers for Irish land during the British Civil Wars
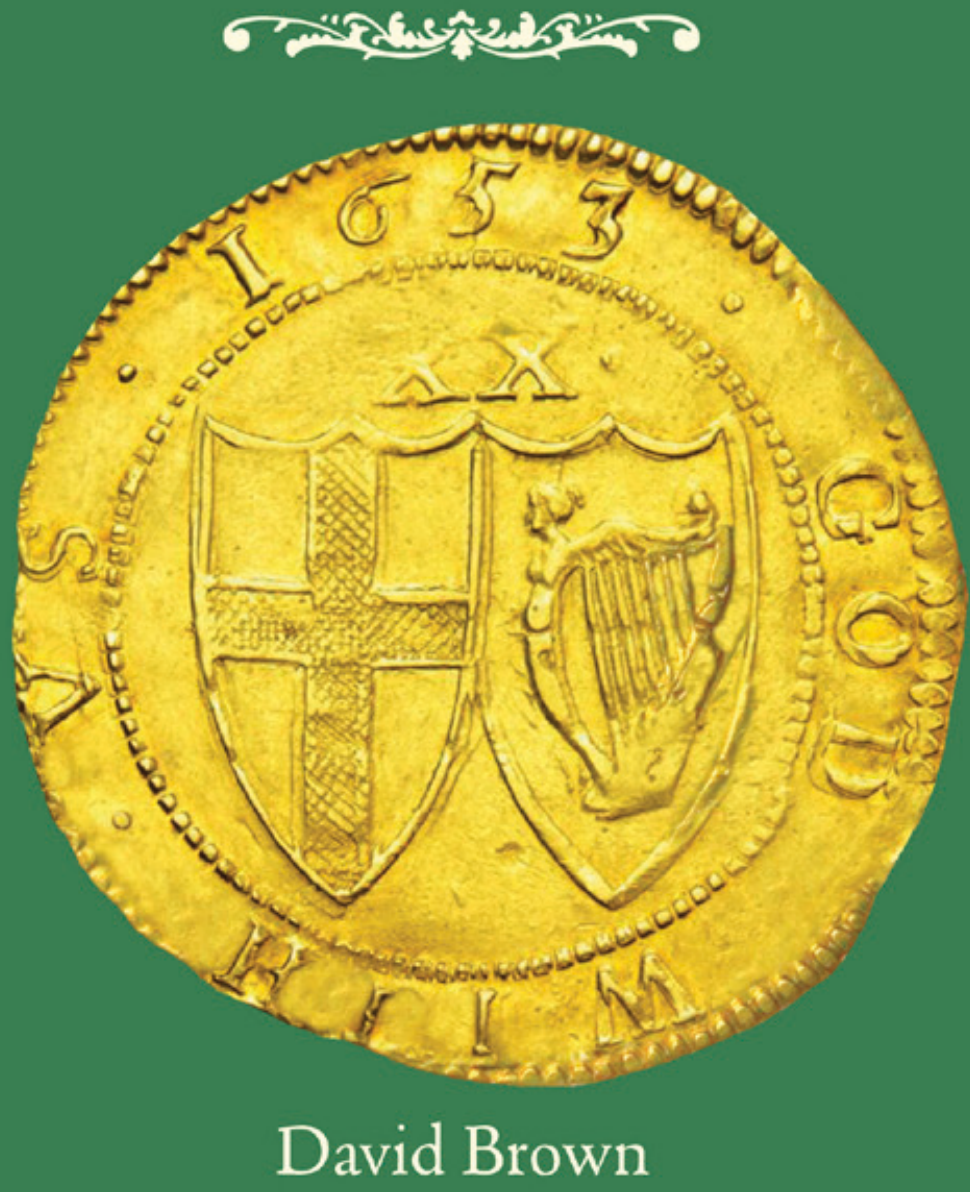


\section{Empire and enterprise

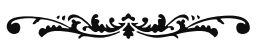

\section{MANCHESTER 1824}

Manchester University Press 


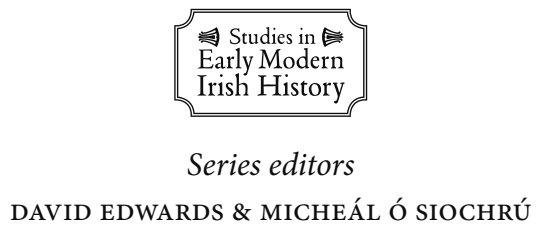

The study of Early Modern Irish History has experienced something of a renaissance in the last decade. However, studies tend to group around traditional topics in political or military history and significant gaps remain. The idea behind this series is to identify key themes and set the agenda for future research.

Each volume in this series comes from leading scholars from Ireland, Britain, North America and elsewhere, addressing a particular subject. We aim to bring the best of Irish historical research to a wider audience, by engaging with international themes of empire, colonisation, religious change and social transformation.

\section{Already published}

The plantation of Ulster: Ideology and practice Micheál Ó Siochrú and Éamonn Ó Ciardha (eds)

Ireland, 1641: Contexts and reactions Micheál Ó Siochrú and Jane Ohlmeyer (eds)

The Scots in early Stuart Ireland: Union and separation in two kingdoms David Edwards and Simon Egan (eds)

Debating Tudor policy in sixteenth-century Ireland: 'Reform' treatises and political discourse David Heffernan

The Irish parliament, 1613-89: The evolution of a colonial institution Coleman A. Dennehy

Ireland in crisis: War, politics and religion, 1641-50

Patrick Little (ed.) 


\section{Empire and enterprise

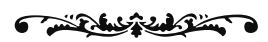

Money, power and the Adventurers for Irish land during the British Civil Wars

DAVID BROWN

Manchester University Press 


\section{Copyright (C) David Brown 2020}

The right of David Brown to be identified as the author of this work has been asserted by him in accordance with the Copyright, Designs and Patents Act 1988.

Published by Manchester University Press

Altrincham Street, Manchester M1 7JA

www.manchesteruniversitypress.co.uk

British Library Cataloguing-in-Publication Data

A catalogue record for this book is available from the British Library

ISBN 9781526131997 hardback

First published 2020

The publisher has no responsibility for the persistence or accuracy of URLs for any external or third-party internet websites referred to in this book, and does not guarantee that any content on such websites is, or will remain, accurate or appropriate.

Typeset by Newgen Publishing UK 